\title{
Material Flow Cost Accounting in Developing Countries: A Systematic Review
}

\author{
Thuy Thanh Tran ${ }^{1,2, *}$ and Christian Herzig ${ }^{1}$ \\ 1 Department of Management in the International Food Industry, University of Kassel, Steinstraße 19, \\ 37213 Witzenhausen, Germany; herzig@uni-kassel.de \\ 2 School of Accounting, University of Economics Ho Chi Minh City, 279 Nguyen Tri Phuong, District 10, \\ Ho Chi Minh City 700000, Vietnam \\ * Correspondence: thuy.tran@uni-kassel.de; Tel.: +49-5542-98-1205
}

Received: 3 June 2020; Accepted: 2 July 2020; Published: 4 July 2020

check for updates

\begin{abstract}
This study aims to provide a better understanding of material flow cost accounting (MFCA) application in developing countries, which are characterized by rapid structure transformation leading to serious environmental problems. By systematically reviewing the existing literature, our analysis of 28 studies from nine developing countries (China, Indonesia, Iran, Malaysia, South Africa, Sri Lanka, Thailand, the Philippines, and Vietnam) shows that MFCA research has primarily focused on Asian developing countries. Moreover, while the use of MFCA is often associated with improving eco-efficiency, the reviewed studies also indicate a high relevance for strategic decision-making processes within organizations. Finally, one of the key challenges in MFCA application reported in developing country studies lies in existing accounting systems with limited data availability and insufficient cost allocation. Based on our findings and gaps identified in the MFCA literature, we suggest paths for further research, including the necessity of quantitative research and comparative analysis of MFCA application across countries, the further investigation of MFCA application in small and medium-sized enterprises as well as in various manufacturing and service sectors in developing countries.
\end{abstract}

Keywords: material flow cost accounting; MFCA; developing countries; systematic review

\section{Introduction}

The objective of this study is to provide a review of the existing literature on material flow cost accounting (MFCA) application in developing countries. There are two major reasons for conducting this review. First, although there is a considerable increase in the quantity of studies and special issue call for papers from peer-reviewed journals on accounting in developing countries [1-3], MFCA research has been largely neglected so far. Second, reviews which addressed MFCA in literature have mainly focused on MFCA practices in general [4-7] rather than examining specific regions (e.g., developing countries).

In recent years, developing countries, which are characterized by rapid structure transformation from the agriculture sector to industry and service sectors, have increasingly been confronted by environmental problems including the high consumption of natural resources and massive industrial waste [8-12]. In response to environmental problems, industries in developing countries have made their efforts in adopting various approaches to resource efficiency improvement and waste reduction. A promising tool in this regard is MFCA, as it supports organizations in achieving both economic and environmental performance by analyzing physical material and energy flows as well as related costs [13-15].

Using Tranfield et al.'s [16] methodology for systematic reviews, we found three key findings: 
- First, it reveals a strong bias towards Asian regions in the scope of MFCA research.

- Second, it enhances a better understanding of the use of MFCA beyond eco-efficiency by identifying its benefit for strategic decision-making processes.

- Third, it identifies current accounting systems in developing countries as one of the key challenges in MFCA application.

Drawing from the above findings and gaps in MFCA literature, we describe future paths in MFCA research including the investigation of the current rate of MFCA application and factors influencing the application of MFCA in developing countries by quantitative research, the comparative analysis of various important aspects of MFCA application across these countries, the examination of MFCA application in small and medium-sized enterprises (SMEs), and of the further spread of MFCA application in various manufacturing and service industries in these countries.

The paper is structured as follows. The next section provides a brief introduction to MFCA and general characteristics of accounting in developing countries. Section 3 explains the methodology used to undertake the systematic review. Section 4 highlights our results, which are summarized in various tables together with detailed analysis. This is followed by Section 5 , in which our discussion and implications for future research are presented. Section 6 concludes the paper.

\section{MFCA and Accounting in Developing Countries}

We start with introducing MFCA and its development. Then, the criteria for choosing developing countries as well as accounting characteristics of these countries are presented.

\section{1. $M F C A$}

MFCA is regarded as an effective tool to achieve both environmental and economic performance by analyzing both physical flows and monetary units. It appeared in the early 1990s within an environmental management project at the Kunert company in Southern Germany [17]. Since then, it has received considerable attention in practice and academia $[13,14,18,19]$, bringing together a wide range of different perspectives, such as cleaner production, ecological economics, and management accounting (MA) [7]. Under MFCA, the implementation process includes five steps: (1) engaging management and determining roles and responsibilities; (2) identifying scope and boundary of the process and establishing a material flow model; (3) allocating costs (material cost, energy cost, system cost, and waste management cost); (4) interpreting and communicating MFCA results; and (5) improving production practices and reducing material loss through MFCA results [13]. These steps have been formulated as a general framework by the International Organization for Standardization in ISO 14051, followed up by ISO 14052, which focuses on the practical implementation of MFCA in a supply chain and ISO 14053, which focuses on the practical implementation of MFCA in SMEs.

Overall, MFCA has become one of the most promising tools for environmental accounting and accountability. It is a key component of the Environmental Management Accounting (EMA) framework published by Burritt et al. [20]. Besides becoming an international standard in ISO (14051, 14052, and 14053), there is also a growing number of guidance documents on MFCA published by governments and associations [18,21,22]. Meanwhile, a large number of case studies spreading throughout many countries over the world have also demonstrated the effectiveness of MFCA in enhancing corporate environmental and financial performance [19,23,24]. Previous MFCA reviews have provided academics, practitioners, and other interested parties with a deeper understanding of MFCA application and diffusion [4-7]. For example, Schaltegger and Zvezdov [7] developed a framework for MFCA to support a wide variety of decision situations. Another example is that of Christ and Burritt [4] who raised notable problems such as a lack of knowledge and application of MFCA in practice or the need for survey, interview, and statistical research methods to supplement case studies. Moreover, at the time their review was conducted, the evidence on MFCA was limited to three studies from developing countries. With a small amount of such studies, it appears to be 
helpful to provide a broader understanding of the current state of MFCA application across developing countries and how research into this stream has developed since then.

\subsection{Accounting in Developing Countries}

As of today, there are different criteria to classify world economies, such as gross national income (GNI) per capita (focus on income) of the World Bank [25], Human Development Index (focus on a long and healthy life, knowledge, and a standard of living) of the United Nations Development Programme [26], or aggregation methods (focus on income and fuel exporters/importers) of the United Nations [27]. In this paper, despite the debate and difficulty of defining developing countries in term of various measurable aspects [28], we used the classification of the World Bank as used in previous studies on accounting [1,2,29]. This includes four categories: high income, upper-middle income, lower-middle income, and low income. Accordingly, developing countries are not listed among high-income economies.

Accounting in developing countries has been dominated by financial accounting rather than MA due to the effects of professional bodies, legal regulations, and education and training [30]. Nonetheless, MA has been broadly applied and has transformed from traditional techniques to contemporary techniques due to various reasons, such as foreign capital's support [31], government reform, or global competition [32]. Despite its transformation, introducing MA innovations has proven to be challenging as traditional MA techniques have commonly been used in many developing countries and there is the effect of culture on MA practices [33-35]. For example, Indian companies used more traditional MA practices than those in Australian companies, and adopted contemporary techniques more slowly than those in Australian companies [33]. Another example is that traditional MA techniques (budgeting and standard costing) were accepted in Malaysian companies while there were the very low levels of adoption of MA innovations (target costing and balanced scorecard) [34].

In recent years, EMA has emerged as the next step in the evolution of MA [36] in order to help organizations increase both economic and environmental performance. Whilst research on EMA and MFCA has been dominated by European and Australian researchers for a long time [37], with little attention being paid to developing economies [38], many scholars have increasingly become interested in these new accounting tools in the context of emerging countries [19,39-41]. There are such interests in emerging countries, as these countries have an entirely different social-political environment and accounting practices [42-45] which have affected EMA and MFCA development and motivated the adaptation and testing of tools in respective contexts [19]. For example, due to the weakness of legislation, Chinese companies will not increase their costs of environmental investment unless legal requirements are strong enough to make pressure for them [44]. Another example is that while courses on environmental accounting have been well set up at universities in developed countries such as Australia and the United Kingdom [45], there has been a lack of these courses at universities in developing countries. In addition, applying models or hypotheses already accepted in developed countries to developing countries could be problematic or unsuitable.

\section{Methodology}

We conducted a systematic review to synthesize and appraise the existing studies on MFCA application from the perspective of developing countries. Our review was guided by Tranfield et al.'s [16] approach including three main stages: (3.1) planning the review, (3.2) conducting the review, and (3.3) reporting the review.

\subsection{Planning the Review}

At the stage of planning, we prepared a review protocol comprising review question, key words, inclusion criteria, and exclusion criteria. The research question was: What is the current state of knowledge concerning MFCA application in developing countries? To answer this question, keywords were limited to "material and energy flow cost accounting", "material flow cost accounting", 
"MFCA", "flow cost accounting", "energy cost accounting", "material flow accounting", "input/output balance", "ISO 14051", and "ISO 14052". Subsequently, the above keywords were searched from five databases: ISI Web of Science, ScienceDirect, ProQuest, SpringerLink, and Emerald. To identify relevant publications, we specified inclusion and exclusion criteria, as shown in Table 1.

Table 1. Selection Criteria of the Systematic Review.

\begin{tabular}{cccc}
\hline No. & Criteria & Inclusion & Exclusion \\
\hline 1 & Publication type & Articles, books, conference papers & Any other publication type \\
2 & Theme & Material flow cost accounting & Any other research area \\
3 & Availability & Full text & Not available as full text \\
4 & Language & English & Any other language \\
5 & Location & Developing countries & Developed countries \\
6 & Level & Corporate level & Any other level \\
\hline
\end{tabular}

\subsection{Conducting the Review}

At the stage of conducting, we selected and appraised relevant studies through inclusion and exclusion criteria identified at the previous stage. Searching for studies based on keywords in five databases revealed 1147 publications that were stored in the bibliographic management software Citavi 6.0. To filter relevant publications, we applied the process suggested by Viegas et al. [46]. This process consists of four steps as follows: (1) elimination of repeated or duplicate publications, (2) alignment of the titles with the theme, (3) alignment of abstracts with the theme, and (4) availability of full-text publications in the databases. After eliminating redundant publications within and between databases, a total of 684 publications were kept. From the selected publications, we reduced 565 publications on an analysis of the title and abstract. As a result, 119 publications were included after screening. In the last step of this process, we excluded 5 publications due to a lack of availability. As a result, 114 relevant publications with full text were chosen. After that, we eliminated 3 publications not written in English, 71 publications due to location criteria, and 12 publications because they were not examining MFCA at corporate level.

\subsection{Reporting Results}

Figure 1 presents a PRISMA (Preferred Reporting Items for Systematic Reviews and Meta-Analyses) flow diagram of the literature selection process, resulting in 28 publications found in the review.

All 28 publications were extracted into a Microsoft Excel worksheet for in-depth analysis. We followed previous studies on the systematic review [16,47] and used an analytic framework with guiding questions including bibliographic analysis, background analysis, and thematic analysis, as shown in Table 2.

Table 2. An Analytic Framework.

\begin{tabular}{cc}
\hline Categories and Sub-Categories & Questions \\
\hline Bibliography & \\
Year & In which year was the publication published? \\
Type & What is the kind of publication? \\
Journal's name & If it is a journal, what is the journal's name? \\
Journal's discipline & What is the journal's discipline? \\
Authors' name & Who are the publication's authors? \\
Authors' geographic origin & What is the geographic origin of the authors? \\
Authors' discipline & What are the author's disciplines? \\
Background & \\
Methodology & What is the methodology used in research? \\
Location & Which country does the publication focus on?
\end{tabular}


Table 2. Cont.

\begin{tabular}{cc}
\hline Categories and Sub-Categories & Questions \\
\hline Size & Which size is subject of the publication? \\
Industry & Which industry sector is subject of the publication? \\
Benefits & What are MFCA application's benefits described in the publication? \\
Process & How were MFCA application's steps described in the publication? \\
Enablers and barriers & What are the enablers of and barriers to MFCA application described in \\
& \\
the publication?
\end{tabular}

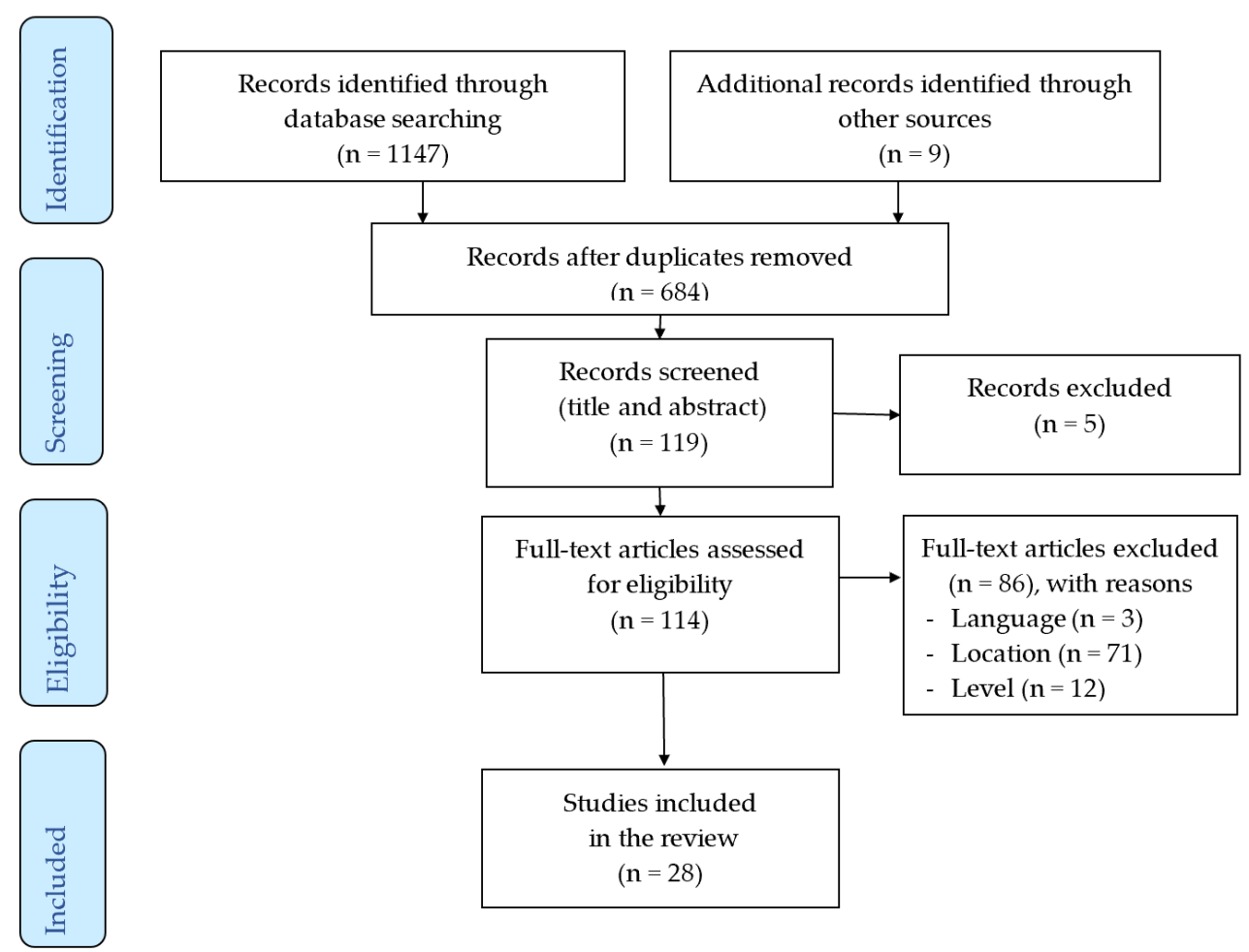

Figure 1. PRISMA Flow Diagram.

\section{Analysis of Results}

This section is structured as follows. First, bibliographic findings are analyzed by year, type, and author. Second, publications are characterized according to methodology, location, size, and industry. Finally, themes of publications are synthesized.

\subsection{Bibliographic Findings}

In our review, we identified 28 publications published during ten years between 2009 and 2018. Given that our review covers one decade, the total number of publications is relatively low. Figure 2 shows fluctuations in the volume of MFCA publications in developing countries.

Starting from one publication in 2009 [48], there is a notable increase in the number of publications in 2012. Three years later, in 2015, the number of yearly publications reaches its peak, accounting for one-fourth of total publications. This turning point can be explained in terms of an edited book and a special issue published in these two years. First, the book by Herzig et al. [19] on EMA case studies of South-East Asian companies contributes to four out of six publications in 2012. This book resulted from a large EMA capacity building and research program in South-East Asia which was carried out between late 2003 and early 2008, funded by the German Federal Ministry for Economic Cooperation and Development [49]. Second, the special issue of the Journal of Cleaner Production attracted 
many MFCA publications in 2015, out of which three publications focused on MFCA application in developing countries.

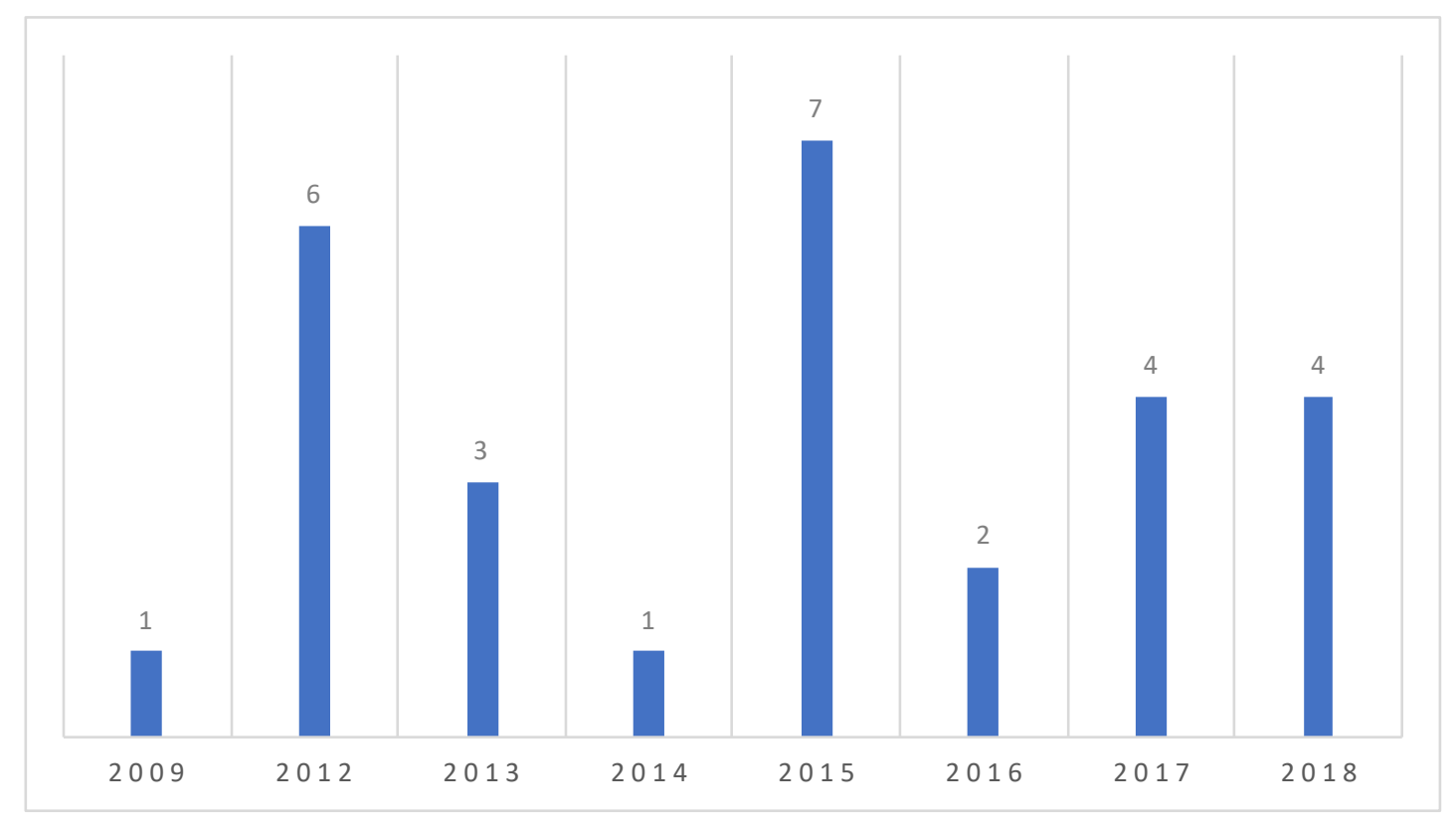

Figure 2. Studies on Material Flow Cost Accounting (MFCA) Application in Developing Countries from 2009 to 2018.

There are three types of publications found in our review: journal articles (in total: 16; $58 \%)$, conference papers $(6 ; 21 \%)$, and book chapters $(6 ; 21 \%)$. Articles published in journals are related to the discipline of environmental and sustainability management (Journal of Cleaner Production; Environment, Development and Sustainability; International Journal of Environmental Science and Development), accounting (Asian Journal of Accounting and Governance; Asia-Pacific Management Accounting Journal; Journal of Accounting and Management), and governance and control (Risk Governance \& Control: Financial Markets \& Institutions). The distribution of journal articles is presented in Table 3. Notably, journals with the most publications on MFCA in developing countries are not accounting journals. While the Journal of Cleaner Production alone accounts for 10 out of 16 journal articles, only three articles could be found in three different accounting journals. However, following rankings such as the ranking of the Chartered Association of Business Schools, these accounting journals are not highly ranked. We could not find papers on MFCA in developing countries from well-known journals in the field of accounting, such as Accounting, Organizations and Society; Accounting Forum; Management Accounting Research; and Accounting, Auditing \& Accountability Journal.

Table 3. MFCA Publications in Developing Countries by Journals.

\begin{tabular}{cc}
\hline Journal Name & Number of Publications \\
\hline Journal of Cleaner Production & 10 \\
Environment, Development and Sustainability & 1 \\
International Journal of Environmental Science and Development & 1 \\
Asian Journal of Accounting and Governance & 1 \\
Asia-Pacific Management Accounting Journal & 1 \\
Journal of Accounting and Management & 1 \\
Risk Governance \& Control: Financial Markets \& Institutions & 1 \\
Total & $\mathbf{1 6}$ \\
\hline
\end{tabular}


In our review sample, 56 different authors contribute to the literature of MFCA in developing countries. The following observations could reflect the novelty of MFCA, which is being researched by scholars from many different countries and disciplines. An interesting observation can be made by looking at the major contributors since it could enrich the knowledge about who mainly contributed to the development of MFCA literature in developing countries. It appears surprising that the top four authors come from developed countries, although other authors coming from developing countries are also interested in this field. Specifically, three authors (Stefan Schaltegger, Tobias Viere, and Christian Herzig), who contributed a high number of publications on MFCA in developing countries, come from Germany in which research on MFCA has a long-standing history. Moreover, it is notable that Roger Burritt coming from Australia and Chompoonoot Kasemset coming from Thailand (however, based in the United Kingdom) also contributed a considerable number of publications on this topic. Other major authors mainly come from developing countries such as Malaysia (Denny Ng, Mohd Norhayati, Maliah Sulaiman), Thailand (Watcharin Chaiwan, Rungchat Chompu-inwai), and South Africa (Michael Fakoya). Although studies on MFCA have received attention from a very small group of researchers, our review shows a wide variety of authors coming from both developed countries and developing countries, which has been not explicitly presented in prior studies $[4,50]$. A further interesting observation is that publications are often developed by a team of authors coming from various disciplines, bringing together perspectives in accounting (e.g., Michael Fakoya), management (e.g., Christian Herzig), life cycle assessment (e.g., Tobias Viere), engineering (e.g., Chawis Boonmee), and environmental science (e.g., Nova Ulhasanah). This result shows that MFCA knowledge has been enriched by diverse and interdisciplinary perspectives rather than only focusing on accounting research.

\subsection{Background of Publications}

As can be seen in Table 4, 26 out of 28 publications used a qualitative research design (case studies). This number illustrates a general trend in MFCA research as it is a suitable strategy during the first stages of investigating the implementation of MFCA in developing countries because the case method is suitable for exploratory research [51]. However, case studies primarily investigate MFCA implementation at one company in a specific country [52-54] rather than examining multiple cases across sectors and/or countries (e.g., comparative research designs). Two papers used a quantitative method to collect data by conducting a survey [55,56]. Surveying 123 companies, Salim et al. [55], for example, show that there is a low level of MFCA implementation in Malaysia. Another example is that Yagi and Kokubu [56] analyze the characteristics of material flow management to facilitate the expanded use of MFCA through surveying 101 firms in Thailand.

With regard to the location of MFCA studies, our analysis reveals that MFCA has been studied in nine developing countries, namely, Thailand, China, South Africa, Malaysia, Vietnam, the Philippines, Indonesia, Iran, and Sri Lanka. There is a strong bias towards emerging countries in Asia (86\% of all publications), while Africa accounts for only $14 \%$ of the publications. With ten publications, Thailand attracted many scholars to carry out their research on MFCA application [54,56-64]. Following this country, there are four publications focusing on China, four publications focusing on South Africa, two publications focusing on Malaysia, and two publications focusing on Vietnam.

In terms of size of companies under study, our review shows that there are six publications investigating MFCA in large enterprises [65-70]. Besides, we also found 12 publications examining MFCA in SMEs [48,53,58-61,63,64,71-74]. Concerning SMEs, for example, MFCA helped a Chinese company increase both environmental performance and the community's recognition and trust [48]. Drawing from our review, MFCA application becomes important and potential not only in large enterprises but also in SMEs that has been emphasized in ISO 14051 [13] and ISO 14053 [75]. Due to a lack of information, we could not identify firm size in other publications. 
Table 4. Publications on MFCA in Developing Countries by Method, Location, Size, and Industry.

\begin{tabular}{|c|c|c|c|c|c|}
\hline No. & Method & Location & Size & Industry & Reference \\
\hline 1 & Case study & China & SME & $\begin{array}{l}\text { Construction machinery cab, } \\
\text { the fuel oil tank, the hydraulic } \\
\text { fluid tank, and the hangar }\end{array}$ & [48] \\
\hline 2 & Case study & Thailand & SME & Wood & [59] \\
\hline 3 & Case study & South Africa & Micro & Micro-brewery & [53] \\
\hline 4 & Case study & Thailand & Small & Textile & [64] \\
\hline 5 & Case study & Thailand & Small & Textile & [63] \\
\hline 6 & Case study & Thailand & Medium & Pajamas production & [58] \\
\hline 7 & Survey & Thailand & Not identified & $\begin{array}{l}\text { Agriculture and food, } \\
\text { consumer products, } \\
\text { industrials, property and } \\
\text { construction, resources, } \\
\text { services, and technology }\end{array}$ & [56] \\
\hline 8 & Case study & Indonesia & Large & Textile and towels & [66] \\
\hline 9 & Case study & China & Large & Plastics & [68] \\
\hline 10 & Case study & The Philippines & Small & Electroplating industry & [71] \\
\hline 11 & Case study & Sri Lanka & Not identified & Crepe rubber & [78] \\
\hline 12 & Case study & Iran & Not identified & Oil & [77] \\
\hline 13 & Case study & South Africa & Large & Brewery & [65] \\
\hline 14 & Case study & Vietnam & Small & Seafood & {$[72]$} \\
\hline 15 & Case study & China & Not identified & $\begin{array}{c}\text { Liquid crystal display and } \\
\text { optoelectronic }\end{array}$ & [79] \\
\hline 16 & Case study & Malaysia & SME & $\begin{array}{c}\text { Metal parts for the automotive } \\
\text { industry }\end{array}$ & [73] \\
\hline 17 & Case study & South Africa & Not identified & Hotel & [76] \\
\hline 18 & Case study & The Philippines & Large & Snack & [70] \\
\hline 19 & Survey & Malaysia & Not identified & Manufacturing & [55] \\
\hline 20 & Case study & Thailand & Not identified & Starch and ethanol production & {$[62]$} \\
\hline 21 & Case study & China & Large & Iron and steel & [69] \\
\hline 22 & Case study & Indonesia & Large & Cement & [67] \\
\hline 23 & Case study & Thailand & Medium & Paper & [61] \\
\hline 24 & Case study & Vietnam & Medium & Beer brewing & [74] \\
\hline 25 & Case study & Thailand & SME & $\begin{array}{c}\text { Pottery and decorative } \\
\text { ceramics }\end{array}$ & {$[60]$} \\
\hline 26 & Case study & Thailand & Not identified & Plastics packaging & [54] \\
\hline 27 & Case study & South Africa & Not identified & Paper & [52] \\
\hline 28 & Case study & Thailand & Not identified & Meat ball production & [57] \\
\hline
\end{tabular}

Regarding the industry focus, the review shows that 26 publications concentrated on manufacturing industries while there are two cases in terms of the hotel industry [56,76]. More specifically, some scholars paid attention to some large industries such as oil [77], iron and steel [69], metal parts [73], and other manufacturing industries such as paper production [52,61], textile manufacturing $[58,63,64,66]$, beer brewing $[53,65,74]$, and food $[57,70,72]$. We also found interesting results obtained from one case relating to the hotel industry [76]. This case is the only one focusing on the implementation of MFCA in the service industry. In one other case, agriculture, manufacturing and construction, and service industries were investigated together [56].

\subsection{Themes}

Overall, we found three main themes emerging from analyzing the literature on MFCA application in developing countries: the benefits of MFCA application, the process of MFCA application, and enablers of and barriers to MFCA application. These themes are presented in the following. 


\subsubsection{Benefits of MFCA Application in Developing Countries}

A large variety of benefits from applying MFCA in developing countries could be found. MFCA is shown to assist companies to identify underestimated costs, reduce losses, waste, and environmental impacts [52,63,78,79]; increase product quality and competitiveness [59,62]; improve processes as well as resource efficiency [62,68,77]; and support decision-making [52,53,61,65,70,74]. These benefits, recognized among various contexts and various industries, can be grouped into two broad categories: eco-efficiency and strategic decision-making. Eco-efficiency is defined as "a management philosophy that encourages business to search for environmental improvements that yield parallel economic benefits" [80]. This is a widely acknowledged benefit of EMA application in standards and frameworks such as the ones published by the International Federation of Accountants (IFAC) [81] or the International Organization for Standardization (ISO) [13]. It is interesting to note that our review of the literature also stresses MFCA's role for strategic decisions, which had not been made explicitly by ISO [13]. Strategic decision-making plays a pivotal role in an organization due to its long-term effects [82] and therefore has also been widely addressed in the literature of accounting and control for sustainability strategy [83]. In various studies of our sample, it is shown how MFCA can support managers in ensuring the future sustainability of an organization (e.g., implementing cleaner production processes) [52,61,74]. For example, Herzig et al. [61] show that MFCA information helps managers at a paper manufacturer develop long-term thinking by encouraging greater and cleaner production of Grade A paper and a competitive business strategy for cost reduction.

\subsubsection{Process of MFCA Application in Various Contexts}

MFCA is known as an effective tool with benefits recognized through the process of its application in various contexts. With some slight differences among cases studies in the steps of MFCA application, 23 cases present explicitly how companies applied this tool in practice. For example, Dunuwila et al. [78] describe MFCA application at a crepe company in which the manufacturing process was illustrated in more detail as follows: rubber latex collection, standardization, coagulation, milling, drying, folding, dry blanket milling, cutting, and packing. Based on MFCA calculation, three improvement options regarding reduction of fresh water, chemicals, and electricity use were suggested, leading to a notable reduction in the need for water and electricity, emission of greenhouse gases, and costs at the same time.

As we mentioned in Section 2.1, there are five steps to implement MFCA guided by ISO [13]. These steps are (1) engaging management and determining roles and responsibilities; (2) identifying scope and boundary of the process and establishing a material flow model; (3) allocating costs (material cost, energy cost, system cost, and waste management cost); (4) interpreting and communicating MFCA results; and (5) improving production practices and reducing material loss through MFCA results. In most of the reviewed studies, the first step was presented implicitly at best (or even ignored). An exception is the case of Chompu-inwai and Apinun [60], who describe comprehensively and clearly all steps.

\subsubsection{Enablers of and Barriers to MFCA Application}

Five publications show explicitly enablers of and/or barriers to MFCA application [55,56,65,73,76]. First, Salim et al. [55] highlight that there is a direct positive impact of supplier integration on MFCA application, while companies with bigger ecological environmental uncertainty are less motivated to apply MFCA. Second, Yagi and Kokubu [56] reveal that hazardous waste and raw material management could facilitate the promotion of MFCA. Third, Fakoya and van der Poll [65] emphasize the importance of integrating enterprise resource planning and MFCA to speed up the availability of waste information in terms of both quantity and cost figures to overcome existing challenges at a brewery company. Fourth, Sulong et al. [73] reveal that there are many enablers of MFCA implementation, such as innovative attributes (relative advantage, compatibility, complexity, trialability, observability; see also [84]), type of innovation decision (authority innovation-decision from top managers), communication channels 
(constant meetings and cooperation), nature of social system (top management commitment and team composition), and change agent's promotion efforts. Besides, this study shows barriers to MFCA implementation in the case of the Alpha company, such as performance appraisal issues, and vendor constraint. Fifth, Nyide [76] shows various challenges in terms of MFCA implementation including data accuracy, the understanding of data and capital budgeting, and limited experience and knowledge of MFCA. We also found some additional enablers of and barriers to MFCA implementation in other publications when describing the benefits and steps of MFCA implementation. These are related to supply chain integration $[63,66,70,71]$, environmental strategy $[66,68,70,72]$, support from government $[59,72,78]$, training and education $[48,59,68]$, and the combination of MFCA with other techniques $[60,67,69,79]$.

Current accounting systems including data availability and cost allocation appear to be the key challenge in MFCA application across many cases. In terms of data availability, this challenge was found in six reviewed cases $[52,53,62,65,66,74]$. It is caused by separating database systems between different departments, such as the accounting department, environment department, and production department, hampering the necessary collection of both physical and monetary data. Moreover, data availability in the context of developing countries is different to that of developed countries due to the differences in technological capacity and MA development [30]. While this is seen to be an enabler of MFCA application in prior studies [14,85], our review shows that it represents a barrier to MFCA application in many developing countries. In cases where it was not presented as a barrier to a developing country company (e.g., in the case of Nguyen's [72] MFCA study of a seafood company), this might be due to the fact that the application only focused on one simple process. If the case was expanded to a broader level for all processes, the firm may possibly also struggle with the same problem in terms of data availability. As a consequence of the lack of availability of data, it is reported that costs are difficult to calculate and allocate [62]. While MFCA requires the analysis of each process with sufficient and detailed information about inputs and outputs in both physical and monetary units, a traditional accounting system has no records of costs for each production line or environmental cost classification. As a result, it is hard for accountants to find a reasonable basis for allocating environmental costs, which is consistent with prior studies of EMA [44,81].

\section{Discussion and Implications for Future Research}

\subsection{Empirical Evidence on MFCA Application in Developing Countries}

Despite an increase in MFCA case study research published in recent years [4], the total number of publications concerning MFCA application in developing countries is still limited. Drawing from current literature, our knowledge about the level of MFCA application in emerging countries remains limited to insights from individual company case studies. There is one article showing a low level of MFCA application in the context of Malaysia through surveying 123 enterprises [55]. This provides some first insights into MFCA diffusion in a developing country context as prior survey-based research has been primarily concerned with EMA application in general rather than examining MFCA specifically [4]. Nonetheless, in the study by Salim et al. [55], we are not certain about how many companies know about MFCA, how many companies know about MFCA but not apply it, and how many companies know about MFCA and apply it in practice in the context of developing countries despite many case-based efforts in proving various benefits of MFCA and the ability of its application. Do companies know about MFCA and if yes, what do they know about it? Are (or will) they (be) interested in applying MFCA? In addition, as mentioned in Section 4.3, many enablers of and barriers to MFCA implementation are primarily reviewed through case studies. While there are many empirical studies investigating motivations and challenges in EMA implementation more generally [39,86,87], it becomes a major shortfall in the current MFCA literature. Hence, we argue that quantitative research is necessary to provide a better understanding of practical MFCA application in these countries. Moreover, it seems that capacity development programs can make a positive contribution to the 
dissemination of MFCA in practice [88] and enhancing our knowledge about its dissemination through wider research on MFCA in developing countries. The strong bias towards Asian studies in our sample might be due to a capacity development program carried out in early 2000 in South-East Asia, resulting in the publication of project outcomes (pilot case studies) as well as subsequent research activities in the region [19]. Another reason might be that regional chapters of academic and practitioner networks (such as the Environmental Management Accounting Network-Asia Pacific or the Australasian Centre for Social and Environmental Accounting Research Group) have been most active in these regions for many years. The fact is that studies on MFCA in the regions of Latin America and the Caribbean could not be found and studies on MFCA in the region of Africa are limited to four publications $[52,53,65,76]$ in our review. We propose future research to further investigate MFCA in these regions to fill the gap in the literature. Lastly, the findings and insights are commonly limited to a single company $[48,53]$ or a single country $[55,56]$. A comparison between countries would be difficult to make due to the lack of heterogeneity among studies with regard to perspectives, methods, and sectors. Hence, we suggest future research to further elaborate on MFCA application and diffusion from a comparative perspective, which has received heightened attention in research on MA [89], EMA [90], and corporate social responsibility [91,92], to compare important aspects of MFCA application between countries.

\subsection{MFCA Application in SMEs in Developing Countries}

It is notable that SMEs in emerging countries, which play a vital role in job creation and global economic growth, account for an approximately 67\% share of formal SMEs in the world [93]. Nonetheless, there are many key constraints to SMEs in developing countries, such as access to finance, competition, and taxation [94]. For example, while on average $43 \%$ of businesses with 20 to 99 employees rate access to finance as a major constraint to current operations in low-income countries, only $11 \%$ of businesses of the same size rate access to finance as a constraint in high-income countries [95]. Due to capital intensity, SMEs in developing countries are less productive and contribute less productivity growth than large firms. While large firms are both more innovative and more productive, SMEs are less likely to engage in increasing innovation and productivity [93]. MFCA is regarded as an innovative approach which could help organizations in enhancing economic and environmental performance. Despite its benefits, we argue that constraints of SMEs in developing countries seem to hamper MFCA application in these nations. Priorities of SMEs in developing countries include seeking short-term profits and minimizing taxation rather than focusing on solving environmental problems derived from their activities. For example, SMEs in Thailand tend to cut production costs, and usually do not know how to manage waste effectively despite very high resource consumption rates [59]. In addition, due to resource constraints, for SMEs it is difficult to "hire some environment accountants to implement the environment budget method and the environmental protection achievement examination system" [48] (p. 32). We think that leaders of enterprises could hesitate to invest in an innovative approach such as MFCA since they are not certain about the benefits that this approach could bring as well as potential costs that they need to spend. While there are nearly 21 million SMEs in developing countries [94], MFCA literature has investigated a minority of these enterprises (e.g., 12 publications found in our review). Hence, future research could further investigate how MFCA could be applied in SMEs in developing countries to overcome their existing constraints. Drawing from our review, the effect of firm size on MFCA implementation was not investigated. Therefore, we also call for conducting more studies to fill this gap in the current literature.

\subsection{MFCA Application in Manufacturing and Service Sectors in Developing Countries}

Developing countries are characterized by the process of rapid industrialization. As a result, structural transformation started mostly in the 1900s and the economy has significantly moved from the agriculture sector to industry and service sectors [8]. According to the World Development Indicators of the World Bank in March 2016, the average value added (\% GDP) in the agricultural, industry, and service sectors were $40 \%, 20 \%$, and $40 \%$, respectively, in 1960 and $20 \%, 30 \%$, and 50\%, respectively, 
in 2010. In addition, the industrialization in developing countries has also led to a considerable increase in economic growth. According to data from the International Monetary Fund in 2019, GDP growth was $4.6 \%$ for developing countries while it was $1.7 \%$ for developed countries. Some emerging nations experienced high growth rates, such as China (5.8\%), the Philippines $(6.2 \%)$, and Vietnam $(6.5 \%)$. Nonetheless, the industrialization in these nations has increasingly produced adverse environmental problems due to the release of air and water pollutants and the disposal of hazardous wastes. Overall, developing countries often demonstrate a lack of attention to environmental protection, inappropriate or ineffective environmental standards, and underdeveloped pollution control techniques.

Mani and Wheeler [96] revealed that the top ten pollution-intensive industries include iron and steel, non-ferrous metals, industrial chemicals, petroleum refineries, non-metallic mineral products, pulp and paper, other chemicals, rubber products, leather products, and metal products. In our review, there is one case in iron and steel, one case in the oil industry, one case in metal parts, and two cases in paper production. As we mentioned in Section 4.2 in terms of sub-industry sectors, some major industries in the economy of developing countries, which have made a strong and negative impact on the environment, are missing in MFCA literature, such as chemicals and chemical products $(12.1 \%$ of GDP in 2015) and non-metallic mineral products (5.5\% of GDP in 2015) [97]. Hence, the lack of data on multiple sectors appears to be a gap in current knowledge. It seems necessary to examine further how MFCA application could improve companies' economic and environmental performance in manufacturing sectors in which there are both high contributions to GDP and intensive pollution (for example, manufacturing of basic metals accounts for 10.7\% of GDP in developing countries while it accounts for 4.6\% of GDP in developed countries in 2015 [97]). Besides, in our review, there are two publications concerning the service industry [56,76]. Although other scholars have already recommended future research to further investigate MFCA in the service industry (e.g., Christ and Burritt [4]), there seems to be still a need to do more in this regard. Not surprisingly, MFCA tends to be applied in industries with significant material and energy flows; however, given the importance of the service industry in the economy of developing countries as well as the cumulative impacts related to this industry, it remains an important call for future research.

\section{Conclusions}

This paper provides a better understanding of MFCA application in developing countries. Our study has shown that MFCA research has primarily focused on Asian developing countries. Moreover, while the use of MFCA is often associated with improving eco-efficiency, the reviewed studies also indicate a high relevance for strategic decision-making processes within organizations. Finally, one of the key challenges in MFCA application reported in developing country studies lies in existing accounting systems with limited data availability and insufficient cost allocation.

Nonetheless, this research was also confronted with some limitations. The first limitation relates to databases used to search relevant publications. It is possible that publications matching the research focus have been not found because they are contained in other databases. The second limitation refers to language, since some studies might have not been conducted in English.

Based on our findings and gaps identified in the MFCA literature, we suggest paths for further research as follows. First, quantitative research is necessary to better understand the current level of MFCA application as well as to confirm factors that have been shown to influence MFCA implementation in developing countries by exploratory case study research, and also in other regions beyond Asia. Second, comparative studies into MFCA application among countries appears promising to better understand the different factors influencing the take-up of innovative accounting methods such as MFCA. Third, future research could further investigate the process of MFCA application in SMEs in developing countries. SMEs play a crucial role in emerging countries [98] and the usage of MA (including MFCA) could be both lower and different in SMEs compared to larger entities [99]. Fourth, in spite of the dominance of research on MFCA in manufacturing industries, future studies could continue to further examine these industries more broadly since "the importance of manufacturing 
industries is increasing in developing economies compared with a declining trend in industrialized economies" [97] (p. 161). Along with manufacturing industries, there is also a need to further investigate MFCA application and diffusion in service industries due to their importance in the economy of developing countries as well as the environmental impacts associated with the service sector.

Author Contributions: Conceptualization, T.T.T. and C.H.; methodology, T.T.T. and C.H.; software, T.T.T.; validation, T.T.T. and C.H.; formal analysis, T.T.T. and C.H.; resources, T.T.T.; data curation, T.T.T.; writing-original draft preparation, T.T.T.; writing — review and editing, T.T.T. and C.H.; visualization, T.T.T.; supervision, C.H.; project administration, T.T.T. and C.H. All authors have read and agreed to the published version of the manuscript.

Funding: The authors acknowledge financial support from the Vietnamese Government Scholarship Programme, Ministry of Education and Training (MOET), the German Academic Exchange Service (DAAD), and the University of Kassel, Germany.

Acknowledgments: The authors are grateful for the anonymous reviewers' constructive feedback and comments on earlier versions of this paper.

Conflicts of Interest: The authors declare no conflict of interest.

\section{References}

1. Van Helden, J.; Uddin, S. Public sector management accounting in emerging economies: A literature review. Crit. Perspect. Account. 2016, 41,34-62. [CrossRef]

2. Alawattage, C.; Wickramasinghe, D.; Tsamenyi, M.; Uddin, S. Doing critical management accounting research in emerging economies. Adv. Sci. Appl. Account. 2017, 10, 177-188. [CrossRef]

3. Ghasemi, R.; Habibi, H.R.; Ghasemlo, M.; Karami, M. The effectiveness of management accounting systems: Evidence from financial organizations in Iran. J. Account. Emerg. Econ. 2019, 9, 182-207. [CrossRef]

4. Christ, K.L.; Burritt, R.L. Material flow cost accounting: A review and agenda for future research. J. Clean. Prod. 2015, 108, 1378-1389. [CrossRef]

5. Guenther, E.; Jasch, C.; Schmidt, M.; Wagner, B.; Ilg, P. Material Flow Cost Accounting_Looking back and ahead. J. Clean. Prod. 2015, 108, 1249-1254. [CrossRef]

6. Rieckhof, R.; Bergmann, A.; Guenther, E. Interrelating material flow cost accounting with management control systems to introduce resource efficiency into strategy. J. Clean. Prod. 2015, 108, 1262-1278. [CrossRef]

7. Schaltegger, S.; Zvezdov, D. Expanding material flow cost accounting. Framework, review and potentials. J. Clean. Prod. 2015, 108, 1333-1341. [CrossRef]

8. Divanbeigi, R.; Paustian, N.; Loayza, N.V. Structural Transformation of the Agricultural Sector: A Primer (English): Research \& Policy Briefs. Available online: http://documents.worldbank.org/ curated/en/561951467993197265/Structural-transformation-of-the-agricultural-sector-a-primer (accessed on 20 January 2020).

9. Dincer, I. Renewable energy and sustainable development: A crucial review. Renew. Sustain. Energy Rev. 2000, 4, 157-175. [CrossRef]

10. Sharvini, S.R.; Noor, Z.Z.; Chong, C.S.; Stringer, L.C.; Yusuf, R.O. Energy consumption trends and their linkages with renewable energy policies in East and Southeast Asian countries: Challenges and opportunities. Sustain. Environ. Res. 2018, 28, 257-266. [CrossRef]

11. Qian, W.; Burritt, R.; Chen, J. The potential for environmental management accounting development in China. J. Account. Organ. Chang. 2015, 11, 406-428. [CrossRef]

12. Kuasirikun, N.; Sherer, M. Corporate social accounting disclosure in Thailand. Account. Audit. Account. J. 2004, 17, 629-660. [CrossRef]

13. ISO. Environmental Management-Material Flow Cost Accounting-General Framework; ISO: Geneva, Switzerland, 2011.

14. Jasch, C. Environmental and Material Flow Cost Accounting: Principles and Procedures; Springer: Dordrecht, The Netherlands, 2009; ISBN 978-1402090271.

15. Huang, S.; Chiu, A.A.; Chao, P.; Wang, N. The application of Material Flow Cost Accounting in waste reduction. Sustainability 2019, 11, 1270. [CrossRef]

16. Tranfield, D.; Denyer, D.; Smart, P. Towards a methodology for developing evidence-informed management knowledge by means of systematic review. Br. J. Manag. 2003, 14, 207-222. [CrossRef] 
17. Wagner, B. A report on the origins of Material Flow Cost Accounting (MFCA) research activities. J. Clean. Prod. 2015, 108, 1255-1261. [CrossRef]

18. METI. Guide for Material Flow Cost Accounting; Japanese Ministry of Economy, Trade and Industry: Tokyo, Japan, 2007.

19. Herzig, C.; Viere, T.; Schaltegger, S.; Burritt, R.L. Environmental Management Accounting: Case Studies of South-East Asian Companies; Routledge: London, UK, 2012; ISBN 9780203125366.

20. Burritt, R.L.; Hahn, T.; Schaltegger, S. Towards a comprehensive framework for Environmental Management Accounting - Links between business actors and Environmental Management Accounting tools. Aust. Account. Rev. 2002, 12, 39-50. [CrossRef]

21. APO. Manual on Material Flow Cost Accounting: ISO 14051. Available online: https://www.apo-tokyo.org/ publications/wp-content/uploads/sites/5/Manual_on_Material_Flow_Cost_Accounting_ISO14051-2014.pdf (accessed on 26 May 2020).

22. The Vietnamese Directorate Standards, Metrology, and Quality. Material Flow Cost Accounting-MFCA: Basic Content and Applied Guideline. Available online: https://cvn.gov.vn/wp-content/uploads/2019/03/17. -LVP-66A-T12.2018.-88t-Sach-MFCA-Final-20.12-mi.pdf (accessed on 26 May 2020).

23. Onishi, Y.; Kokubu, K.; Nakajima, M. Implementing Material Flow Cost Accounting in a pharmaceutical company. In Environmental Management Accounting for Cleaner Production; Schaltegger, S., Bennett, M., Burritt, R.L., Jasch, C., Eds.; Springer Netherlands: Dordrecht, The Netherlands, 2008; pp. 395-409, ISBN 978-1-4020-8912-1.

24. Schmidt, M. The interpretation and extension of Material Flow Cost Accounting (MFCA) in the context of environmental material flow analysis. J. Clean. Prod. 2015, 108, 1310-1319. [CrossRef]

25. The World Bank. World Bank Country and Lending Groups. Available online: https://datahelpdesk. worldbank.org/knowledgebase/articles/906519-world-bank-country-and-lending-groups (accessed on 10 June 2020).

26. United Nations Development Programme. Human Development Index (HDI). Available online: http://hdr. undp.org/en/content/human-development-index-hdi (accessed on 10 June 2020).

27. United Nations. World Economic Situation Prospects. Available online: https://www.un.org/development/ desa/dpad/wp-content/uploads/sites/45/WESP2020_Annex.pdf (accessed on 10 June 2020).

28. Hopper, T.; Lassou, P.; Soobaroyen, T. Globalisation, accounting and developing countries. Crit. Perspect. Account. 2017, 43, 125-148. [CrossRef]

29. Kuttner, M.; Feldbauer-Durstmüller, B. Comparative management accounting in developing countries-State-of-the-art and future perspectives. Int. J. Bus. Res. 2016, 16, 81-104. [CrossRef]

30. Hopper, T.; Tsamenyi, M.; Uddin, S.; Wickramasinghe, D. Management accounting in less developed countries: What is known and needs knowing. Account. Audit. Account. J. 2009, 22, 469-514. [CrossRef]

31. Albu, N.; Albu, C.N. Factors associated with the adoption and use of management accounting techniques in developing countries: The case of Romania. J. Int. Financ. Manag. Account. 2012, 23, 245-276. [CrossRef]

32. Maina Waweru, N.; Hoque, Z.; Uliana, E. Management accounting change in South Africa. Account. Audit. Account. J. 2004, 17, 675-704. [CrossRef]

33. Joshi, P.L. The international diffusion of new management accounting practices: The case of India. J. Int. Account. Audit. Tax. 2001, 10, 85-109. [CrossRef]

34. Smith, M.; Abdullah, Z.; Abdul Razak, R. The diffusion of technological and management accounting innovation: Malaysian evidence. Asian Rev. Account. 2008, 16, 197-218. [CrossRef]

35. Endenich, C.; Brandau, M.; Hoffjan, A. Two decades of research on comparative management accounting-Achievements and future directions. Aust. Account. Rev. 2011, 21, 365-382. [CrossRef]

36. Jasch, C. Environmental management accounting (EMA) as the next step in the evolution of management accounting. J. Clean. Prod. 2006, 14, 1190-1193. [CrossRef]

37. Parker, L.D. Twenty-one years of social and environmental accountability research: A coming of age. Account. Forum 2011, 35, 1-10. [CrossRef]

38. Belal, A.R.; Cooper, S.M.; Roberts, R.W. Vulnerable and exploitable: The need for organisational accountability and transparency in emerging and less developed economies. Account. Forum 2013, 37, 81-91. [CrossRef]

39. Mokhtar, N.; Jusoh, R.; Zulkifli, N. Corporate characteristics and environmental management accounting (EMA) implementation: Evidence from Malaysian public listed companies (PLCs). J. Clean. Prod. 2016, 136, 111-122. [CrossRef] 
40. Jalaludin, D.; Sulaiman, M.; Nazli Nik Ahmad, N. Understanding environmental management accounting (EMA) adoption: A new institutional sociology perspective. Soc. Responsib. J. 2011, 7, 540-557. [CrossRef]

41. Le, T.T.; Nguyen, T.M.A.; Phan, T.T.H. Environmental management accounting and performance efficiency in the Vietnamese construction material industry-A managerial implication for sustainable development. Sustainability 2019, 11, 5152. [CrossRef]

42. Tilt, C.A. Making social and environmental accounting research relevant in developing countries: A matter of context? Soc. Environ. Account. J. 2018, 38, 145-150. [CrossRef]

43. Ali, W.; Frynas, J.G.; Mahmood, Z. Determinants of corporate social responsibility (CSR) disclosure in developed and developing countries: A literature review. Corp. Soc. Responsib. Environ. Manag. 2017, 24, 273-294. [CrossRef]

44. Xiaomei, L. Theory and practice of environmental management accounting. Int. J. Technol. Manag. Sustain. Dev. 2004, 3, 47-57. [CrossRef]

45. Gibson, K. NOTES Courses on environmental accounting. Account. Audit. Account. J. 1997, 10, $584-593$. [CrossRef]

46. Viegas, C.V.; Bond, A.J.; Vaz, C.R.; Borchardt, M.; Pereira, G.M.; Selig, P.M.; Varvakis, G. Critical attributes of sustainability in higher education: A categorisation from literature review. J. Clean. Prod. 2016, 126, 260-276. [CrossRef]

47. Stechemesser, K.; Guenther, E. Carbon accounting: A systematic literature review. J. Clean. Prod. 2012, 36, 17-38. [CrossRef]

48. Weidong, Z.; Ryoichi, N.; Chen, Z.; Pinlong, C. A case study on the implementation of MFCA in SMEs: HNJC company. Asia-Pac. Manag. Account. J. 2009, 42, 29-42.

49. Viere, T.; Herzig, C.; Schaltegger, S.; Leung, R. Partnerships for sustainable business development: Capacity building in South-East Asia. In Partnerships for Sustainable Development: Perspectives from the Asia-Pacific Region; Welford, R., Hills, P., Young, W., Eds.; The Centre of Urban Planning and Environmental Management: Hong Kong, China, 2006; pp. 4-15.

50. Schaltegger, S.; Gibassier, D.; Zvezdov, D. Is environmental management accounting a discipline? A bibliometric literature review. Meditari Account. Res. 2013, 21, 4-31. [CrossRef]

51. Hancock, D.R.; Algozzine, B. Doing Case Study Research: A Practical Guide for Beginning Researchers; Columbia University, Teachers College Press: New York, NU, USA, 2006; ISBN 978-0807758137.

52. Doorasamy, M. The effectiveness of Material Flow Cost Accounting (MFCA) in identifying non-product output costs and its impact on environmental performance in paper manufacturing companies: A case study in Kwa-Zulu Natal. J. Account. Manag. 2014, 4, 51-69.

53. Fakoya, M.B. Adopting material flow cost accounting model for improved waste-reduction decisions in a micro-brewery. Environ. Dev. Sustain. 2015, 17, 1017-1030. [CrossRef]

54. Kasemset, C.; Sasiopars, S.; Suwiphat, S. The application of MFCA analysis in process improvement: A case study of plastics packaging factory in Thailand. In Proceedings of the Institute of Industrial Engineers Asian Conference 2013; Lin, Y.-K., Tsao, Y.-C., Lin, S.-W., Eds.; Springer: Singapore, 2013; pp. 353-361, ISBN 978-981-4451-97-0.

55. Salim, K.M.A.; Amir, A.M.; Sulaiman, M. Material Flow Cost Accounting, perceived ecological environmental uncertainty, supplier integration and business performance: A study of manufacturing sector in Malaysia. Asian J. Account. Gov. 2017, 8, 107-121. [CrossRef]

56. Yagi, M.; Kokubu, K. Corporate material flow management in Thailand: The way to material flow cost accounting. J. Clean. Prod. 2018, 198, 763-775. [CrossRef]

57. Chaiwan, W.; Boonmee, C.; Kasemset, C. Waste reduction in meat processing industry: The application of MFCA (ISO 14051). In Toward Sustainable Operations of Supply Chain and Logistics Systems; Kachitvichyanukul, V., Sethanan, K., Golinska-Dawson, P., Eds.; Springer International Publishing: Cham, Switzerland, 2015; pp. 183-193, ISBN 978-3-319-19005-1.

58. Chattinnawat, W.; Suriya, W.; Jindapanpisan, P. Application of MFCA with LEAN to improve pajama production process: A case study of Confederate International Co., Ltd. In Accounting for Sustainability: Asia Pacific Perspectives; Lee, K.-H., Schaltegger, S., Eds.; Springer International Publishing: Cham, Switzerland, 2018; pp. 209-235, ISBN 978-3-319-70898-0. 
59. Chompu-inwai, R.; Jaimjit, B.; Premsuriyanunt, P. A combination of Material Flow Cost Accounting and design of experiments techniques in an SME: The case of a wood products manufacturing company in northern Thailand. J. Clean. Prod. 2015, 108, 1352-1364. [CrossRef]

60. Chompu-inwai, R.; Apinun, T. The application of Material Flow Cost Accounting for loss reduction in the pottery and decorative ceramics production process. In Proceedings of the 2015 International Conference on Logistics, Informatics and Service Sciences (LISS), Barcelona, Spain, 27-29 July 2015; Zhang, Z., Zhang, R., Fernandez, V., Liu, S., Eds.; IEEE: New York, NY, USA, 2015; pp. 1-6.

61. Herzig, C.; Viere, T.; Schaltegger, S.; Burritt, R.L. Relevant environmental costing and decision-making in a SAA paper manufacturer. In Environmental Management Accounting: Case Studies of South-East Asian Companies; Herzig, C., Viere, T., Schaltegger, S., Burritt, R.L., Eds.; Routledge: London, UK, 2012; pp. 173-190, ISBN 9780203125366.

62. Jakrawatana, N.; Pingmuangleka, P.; Gheewala, S.H. Material flow management and cleaner production of cassava processing for future food, feed and fuel in Thailand. J. Clean. Prod. 2016, 134, 633-641. [CrossRef]

63. Kasemset, C.; Chernsupornchai, J.; Pala-Ud, W. Application of MFCA in waste reduction: Case study on a small textile factory in Thailand. J. Clean. Prod. 2015, 108, 1342-1351. [CrossRef]

64. Kasemset, C.; Boonmee, C. An integration method of MFCA, dynamic programming, and multiple criteria decision making in operations improvement: A case study. In Proceedings of the 2017 IEEE International Conference on Industrial Engineering and Engineering Management (IEEM), Singapore, 10-13 December 2017; IEEE: New York, NY, USA, 2017; pp. 745-749, ISBN 978-1-5386-0948-4.

65. Fakoya, M.B.; van der Poll, H.M. Integrating ERP and MFCA systems for improved waste-reduction decisions in a brewery in South Africa. J. Clean. Prod. 2013, 40, 136-140. [CrossRef]

66. Herzig, C.; Viere, T.; Schaltegger, S.; Burritt, R.L. EMA for eco-efficiency in a towel production firm. In Environmental Management Accounting: Case Studies of South-East Asian Companies; Herzig, C., Viere, T., Schaltegger, S., Burritt, R.L., Eds.; Routledge: London, UK, 2012; pp. 59-75, ISBN 9780203125366.

67. Ulhasanah, N.; Goto, N. Preliminary design of eco-city by using industrial symbiosis and waste co-processing based on MFA, LCA, and MFCA of cement industry in Indonesia. Int. J. Environ. Sci. Dev. 2012, 553-561. [CrossRef]

68. Zhang, B.; Liu, J. Empirical study on MFCA introduced in Sekisui Chemical Group and its enlightenment. In Proceedings of the 3rd International Conference on Advances in Energy and Environmental Science 2015, Zhuhai, China, 25-26 July 2015; Yarlagadda, P., Ed.; Atlantis Press: Paris, France, 2015; pp. 1456-1460, ISBN 978-94-6252-130-8.

69. Zhou, Z.; Zhao, W.; Chen, X.; Zeng, H. MFCA extension from a circular economy perspective: Model modifications and case study. J. Clean. Prod. 2017, 149, 110-125. [CrossRef]

70. Herzig, C.; Viere, T.; Schaltegger, S.; Burritt, R.L. Material flow cost accounting in a snack producer. In Environmental Management Accounting: Case Studies of South-East Asian Companies; Herzig, C., Viere, T., Schaltegger, S., Burritt, R.L., Eds.; Routledge: London, UK, 2012; pp. 98-116, ISBN 9780203125366.

71. Herzig, C.; Viere, T.; Schaltegger, S.; Burritt, R.L. Environmental impact assessment, compliance monitoring and reporting in electroplating. In Environmental Management Accounting: Case Studies of South-East Asian Companies; Herzig, C., Viere, T., Schaltegger, S., Burritt, R.L., Eds.; Routledge: London, UK, 2012; pp. 148-172, ISBN 9780203125366.

72. Nguyen, D.T.T. Is Japanese Material Flow Cost Accounting useful to Vietnam? A case study of a Vietnamese seafood processing company. In Accounting for Sustainability: Asia Pacific Perspectives; Lee, K.-H., Schaltegger, S., Eds.; Springer International Publishing: Cham, Switzerland, 2018; pp. 237-258, ISBN 978-3-319-70898-0.

73. Sulong, F.; Sulaiman, M.; Norhayati, M.A. Material Flow Cost Accounting (MFCA) enablers and barriers: The case of a Malaysian small and medium-sized enterprise (SME). J. Clean. Prod. 2015, 108, 1365-1374. [CrossRef]

74. Schaltegger, S.; Viere, T.; Zvezdov, D. Tapping environmental accounting potentials of beer brewing. J. Clean. Prod. 2012, 29-30,1-10. [CrossRef]

75. ISO. Environmental Management-Material Flow Cost Accounting-Guidance for Practical Implementation in SMEs; ISO: Geneva, Switzerland, 2019.

76. Nyide, C.J. Material flow cost accounting as a tool for improved resource efficiency in the hotel sector: A case of emerging market. Risk Gov. Control: Financ. Mark. Inst. 2016, 6, 428-435. [CrossRef] 
77. Mahmoudi, E.; Jodeiri, N.; Fatehifar, E. Implementation of material flow cost accounting for efficiency improvement in wastewater treatment unit of Tabriz oil refining company. J. Clean. Prod. 2017, 165, 530-536. [CrossRef]

78. Dunuwila, P.; Rodrigo, V.H.L.; Goto, N. Financial and environmental sustainability in manufacturing of crepe rubber in terms of material flow analysis, material flow cost accounting and life cycle assessment. J. Clean. Prod. 2018, 182, 587-599. [CrossRef]

79. Trappey, A.J.C.; Yeh, M.F.M.; Wu, S.C.-Y.; Kuo, A.Y.F. ISO14051-based Material Flow Cost Accounting system framework for collaborative green manufacturing. In Proceedings of the 17th International Conference on Computer Supported Cooperative Work in Design (CSCWD), Whistler, BC, Canada, 27-29 June 2013; IEEE: Piscataway, NJ, USA, 2013; pp. 639-644, ISBN 978-1-4673-6085-2.

80. WBCSD. Eco-efficiency Learning Module. Available online: https:/www.wbcsd.org/Projects/Education/ Resources/Eco-efficiency-Learning-Module (accessed on 10 March 2020).

81. IFAC. International Guidance Document of Environmental Management Accounting; International Federation of Accountants: New York, NY, USA, 2005.

82. Lenz, R.T.; Engledow, J.L. Environmental analysis units and strategic decision-making: A field study of selected 'leading-edge' corporations. Strateg. Manag. J. 1986, 7, 69-89. [CrossRef]

83. Ghosh, B.; Herzig, C.; Mangena, M. Controlling for sustainability strategies: Findings from research and directions for the future. J. Manag. Control 2019, 30, 5-24. [CrossRef]

84. Burritt, R.L.; Herzig, C.; Schaltegger, S.; Viere, T. Diffusion of environmental management accounting for cleaner production: Evidence from some case studies. J. Clean. Prod. 2019, 224, 479-491. [CrossRef]

85. Strobel, M.; Redmann, C. Flow Cost Accounting, an accounting approach based on the actual flows of materials. In Environmental Management Accounting: Informational and Institutional Developments; Bennett, M., Bouma, J.J., Eds.; Kluwer Academic Publishers: Dordrecht, The Netherlands, 2004; pp. 67-82, ISBN 1-4020-0552-0.

86. Christ, K.L.; Burritt, R.L. Environmental management accounting: The significance of contingent variables for adoption. J. Clean. Prod. 2013, 41, 163-173. [CrossRef]

87. Lima Ribeiro, V.P.; Aibar-Guzman, C. Determinants of environmental accounting practices in local entities: Evidence from Portugal. Soc. Responsib. J. 2010, 6, 404-419. [CrossRef]

88. Burritt, R.L.; Herzig, C.; Tadeo, B.D. Environmental management accounting for cleaner production: The case of a Philippine rice mill. J. Clean. Prod. 2009, 17, 431-439. [CrossRef]

89. Wijewardena, H.; de Zoysa, A. A comparative analysis of management accounting practices in Australia and Japan: An empirical investigation. Int. J. Account. 1999, 34, 49-70. [CrossRef]

90. Olalekan, I.O.; Jumoke, O.O. Identifying barriers to environmental management accounting practices: A comparative study of Nigeria and South Africa. Bus. Manag. Rev. 2017, 9, 168-179.

91. Ramasamy, B.; Ting, H.W. A comparative analysis of corporate social responsibility awareness: Malaysian and Singaporean firms. J. Corp. Citizsh. 2004, 109-123.

92. Jamali, D.; Sidani, Y.; El-Asmar, K. A three country comparative analysis of managerial CSR perspectives: Insights from Lebanon, Syria and Jordan. J. Bus. Ethics 2009, 85, 173-192. [CrossRef]

93. Kumar, R. Targeted SME Financing and Employment Effects: What Do We Know and What Can We Do Differently? (English): Jobs Working Paper. Available online: http://documents.worldbank.org/curated/en/ 577091496733563036/Targeted-SME-financing-and-employment-effects-what-do-we-know-and-what-canwe-do-differently (accessed on 6 March 2020).

94. Bruhn, M.; Hommes, M.; Khanna, M.; Singh, S.; Sorokina, A.; Wimpey, J.S. MSME Finance Gap: Assessment of The Shortfalls and Opportunities in Financing Micro, Small, and Medium Enterprises in Emerging Markets (English). Available online: http://documents.worldbank.org/curated/en/653831510568517947/MSMEfinance-gap-assessment-of-the-shortfalls-and-opportunities-in-financing-micro-small-and-mediumenterprises-in-emerging-markets (accessed on 10 March 2020).

95. Bouri, A.; Breij, M.; Diop, M.; Kempner, R.; Klinger, B.; Stevenson, K. Report on Support to SMEs in Developing Countries through Financial Intermediaries. Available online: https:/www.eib.org/attachments/ dalberg_sme-briefing-paper.pdf (accessed on 10 February 2020).

96. Mani, M.; Wheeler, D. In search of pollution havens? Dirty industry in the world economy, 1960 to 1995. J. Environ. Dev. 1998, 215-247. [CrossRef] 
97. UNIDO. Industrial Development Report 2018-Demand for Manufacturing: Driving Inclusive and Sustainable Industrial Development. Available online: https://www.unido.org/resources-publicationsflagship-publications-industrial-development-report-series/industrial-development-report-2018 (accessed on 9 March 2020).

98. World Bank. World Bank Group Support for Small and Medium Enterprises: A Synthesis of Evaluative Findings (English). Available online: http://documents.worldbank.org/curated/en/640401570040096569/ World-Bank-Group-Support-for-Small-and-Medium-Enterprises-A-Synthesis-of-Evaluative-Findings (accessed on 10 March 2020).

99. Lavia López, O.; Hiebl, M.R.W. Management accounting in small and medium-sized enterprises: Current knowledge and avenues for further research. J. Manag. Account. Res. 2015, 27, 81-119. [CrossRef]

(C) 2020 by the authors. Licensee MDPI, Basel, Switzerland. This article is an open access article distributed under the terms and conditions of the Creative Commons Attribution (CC BY) license (http://creativecommons.org/licenses/by/4.0/). 